\title{
Radiolabelled rat uterine luminal proteins and their regulation by oestradiol and progesterone
}

\author{
M. A. H. Surani \\ Physiological Laboratory, University of Cambridge, Cambridge CB2 3EG, U.K.
}

\begin{abstract}
Summary. Radiolabelled uterine luminal proteins were obtained $6 \mathrm{~h}$ after instillation of 5-10 $\mu \mathrm{Ci}\left[{ }^{35} \mathrm{~S}\right]$ methionine into the lumen of each uterine horn of rats. The proteins were analysed electrophoretically on $6 \%$ polyacrylamide gels and incorporation of the precursor into the separated proteins was estimated in $0.18 \mathrm{~cm}$ gel slices by scintillation spectrometry. Major incorporation was obtained on Day 5 of pregnancy in a group of proteins of approximate mol. wt $3 \times 10^{4}, 4.5 \times 10^{4}$ and $5.5 \times 10^{4}$ and in proteins of mol. wt 8-10 $\times 10^{4}$. During pro-oestrus, substantial incorporation of the precursor occurred in a group of proteins of mol. wt 13.5 $\times 10^{4}, 12.5 \times 10^{4}$ and 7.5-8.0 $\times 10^{4}$ and slight incorporation in proteins of mol. wt $4.5 \times 10^{4}$. These changes were mimicked in ovariectomized females by injections of appropriate steroids: progesterone and oestradiol were necessary to induce the proteins detected during pregnancy, oestradiol alone was able to reproduce the changes observed at pro-oestrus. The proteins in the lumen appear to be of uterine origin because radiolabelled serum proteins were not detected in the lumen after an i.p. injection of the isotope. Also, labelled proteins were detected in the horn receiving the isotope but not in the contralateral horn injected with saline. Cycloheximide, given i.p. simultaneously with the isotope, suppressed synthesis of uterine proteins.
\end{abstract}

\section{Introduction}

The ovarian steroids are involved in the control of uterine growth, both hypertrophic (Hsueh, Peck \& Clark, 1975) and hyperplastic (Tachi, Tachi \& Lindner, 1972), cytodifferentiation, and for the sensitization of the uterus for embryo implantation (Psychoyos, 1973).

The intricate nature of steroid action on the uterus is partly reflected in the changes in the uterine luminal proteins which undergo modifications with the changing endocrine state of females (Surani, 1977a). Previous analyses of samples of uterine fluid at particular moments (Surani, 1975a, 1976, 1977a, b; Webb \& Surani, 1975; Gore-Langton \& Surani, 1976) have been useful for distinguishing proteins which are present in bulk, but quantitatively meagre proteins may have been overlooked although their biological significance could be considerable.

Attempts to detect specific protein in the rat uterine lumen by immunological methods have given inconclusive results, probably because uterine proteins may be present in small amounts at any particular time although they may be synthesized continuously. Up to four uterine-specific proteins and some serum-derived proteins have been reported (Albers \& Neves e Castro, 1961; Kunitake, Nakamura, Wells \& Moyer, 1965; Ying \& Greep, 1972), but Beck \& Boots (1973) were unable to detect any uterine-specific macromolecules. In the present study, an attempt was made to detect uterine-specific proteins by analyses of radiolabelled luminal proteins after incorporation of $\left[{ }^{35} \mathrm{~S}\right]-$ methionine.

\section{Materials and Methods}

Female Wistar rats weighing $180 \mathrm{~g}$ were used. Vaginal smears were examined daily for 2 cycles and 15 females were used on the morning of pro-oestrus. A further 50 females were mated (day of spermatozoa in vaginal smear $=$ Day 1 of pregnancy) and were killed on Days 3 or 5 (day of implantation) of 
pregnancy. Virgin females (50) were bilaterally ovariectomized and left for 3 weeks before treatment with exogenous hormones.

Two hormonal regimens were used. Females in Group I (25) were given a s.c. injection of $2.0 \mathrm{mg}$ progesterone (4-pregnen-3,20-dione: Koch Light Laboratories) $+1 \cdot 0 \mu \mathrm{g}$ oestradiol benzoate $(1,2,5(10)$-oestratrien-3, 17 $\beta$-diol 3-benzoate: Koch Light Laboratories) in $0.2 \mathrm{ml}$ arachis oil. Daily injections of $2.0 \mathrm{mg}$ progesterone in $0.2 \mathrm{ml}$ arachis oil were then given for 10 days. On the 10 th day, an injection of $1.0 \mu \mathrm{g}$ oestradiol $+2.0 \mathrm{mg}$ progesterone in $0.2 \mathrm{ml}$ arachis oil was given to each of 20 females and time-course studies on the synthesis of luminal proteins were carried out for up to $24 \mathrm{~h}$ $(5$ females every $6 \mathrm{~h}$ ). Group II females (25) each received injections of $1.0 \mu \mathrm{g}$ oestradiol in $0.2 \mathrm{ml}$ arachis oil every $24 \mathrm{~h}$ for up to 4 days. Eight females were also given $2.0 \mathrm{mg}$ progesterone/day on the last 2 days. Groups of 4 or 5 females were killed every $24 \mathrm{~h}$. Intraluminal injections of $5-10 \mu \mathrm{Ci}$ ${ }^{[35}$ S]methionine (sp. act. $330 \mathrm{Ci} / \mathrm{mmol}$ : Radiochemical Centre) were given in $25 \mu \mathrm{l} 0.01 \mathrm{M}$ phosphate-buffered saline (PBS). Females were lightly anaesthetized with ether and after mid-ventral incision the cervical end of the uterus was ligated before intraluminal instillation of the precursor at the oviductal end through a 27 -gauge needle. The needle was removed gradually, $30 \mathrm{sec}$ after the injection and the site of injection cauterized. Ligation and cauterization was essential to prevent an escape of the precursor although this was sometimes unavoidable. In females in which fluid had accumulated in the uterus (pro-oestrous and Group II females), the fluid (70-200 $\mu \mathrm{l}$ ) was aspirated before the injection. All animals were allowed to recover and killed $6 \mathrm{~h}$ after the methionine instillation.

Two further experiments were carried out to test whether protein synthesized peripherally entered the lumen during the periods involved because serum proteins became labelled with methionine after the intraluminal injection of $\left[{ }^{35}\right.$ S $]$ methionine. Four pro-oestrous and 4 pregnant (Day 5) females were each given an i.p. injection of $50 \mu \mathrm{Ci}\left[{ }^{35}\right.$ S $]$ methionine in $0.5 \mathrm{ml}$ PBS. The cervical ends of the uterine horns were ligated as described above and $25 \mu$ PBS were injected into each horn before the precursor injection. In the other experiment, one uterine horn of each of 6 pro-oestrous or 6 pregnant (Day 5) females was injected with the radioactive precursor and PBS was injected into the contralateral horn. Ligatures were placed at each end of the horn immediately above the cervical junction. Samples from two females were combined but the material from the precursor-injected horns and PBS-injected horns was analysed separately.

\section{Injection of cycloheximide}

Cycloheximide, a translational inhibitor of protein synthesis, was used to determine if the uterine synthesis of proteins could be prevented. Twenty pregnant females (Day 5) were each given an i.p. injection of $400 \mu \mathrm{g}$ cycloheximide (Sigma), dissolved in $0.5 \mathrm{ml} \mathrm{PBS}$, immediately or at 2 or $4 \mathrm{~h}$ after the intraluminal injections of methionine. The females were killed $6 \mathrm{~h}$ after methionine injection.

\section{Collection of samples}

The animals were lightly anaesthetized with ether, decapitated and exsanguinated. Uterine fluid was collected by flushing with $0.2 \mathrm{ml} 0.01 \mathrm{M}$-phosphate buffer $(\mathrm{pH} 7 \cdot 0)$ or aspiration as described previously (Surani, 1977a). Aspiration was usually required for the pro-oestrous females and the ovariectomized females receiving oestradiol alone (Group II). Aspirates and flushings were analysed separately. All samples were kept on ice. After centrifugation at $12,000 \mathrm{~g}$ at $4^{\circ} \mathrm{C}$ for $1 \mathrm{~h}$, each sample was diluted to give $10 \times 10^{4}$ or $2 \times 10^{4} \mathrm{ct} / \mathrm{min}$ in $0.2 \mathrm{ml}$ buffer.

\section{Analyses of uterine samples and preparation of gel slices}

The samples were prepared for electrophoresis as described by Surani (1977a) and the proteindodecyl sulphate complexes were separated electrophoretically on $6 \%$ polyacrylamide gels calibrated for molecular weight estimates (Surani, 1977a). The $8.5 \mathrm{~cm}$-long gel columns were fixed in $7.5 \%$ acetic 
acid $/ 5 \%$ methanol after electrophoresis and repeatedly washed in this solution for $24 \mathrm{~h}$ to remove unincorporated precursor. The gel columns expand in this fixative to about $9.3 \mathrm{~cm}$ in length. The gels were rinsed once in distilled water and dried immediately on tissue papers. 50-55 slices, each approximately $0.18 \mathrm{~cm}$ thick, were obtained from each gel column with a manual transverse gel slicer. The discs were placed in individual scintillation vials with $0.5 \mathrm{ml}$ Soluene-350 (Packard), the caps were firmly replaced and the vials left overnight at $60^{\circ} \mathrm{C}$. Scintillation fluid $(10 \mathrm{ml})$ was added to each vial. The scintillation fluid consisted of $5.5 \mathrm{~g}$ Permablend III/1 toluene (Permablend III is $91 \%$ PPO and $9 \%$ bis-MSB: Packard). The vials were left in the dark overnight and counted in a Tracerlab Scintilla-

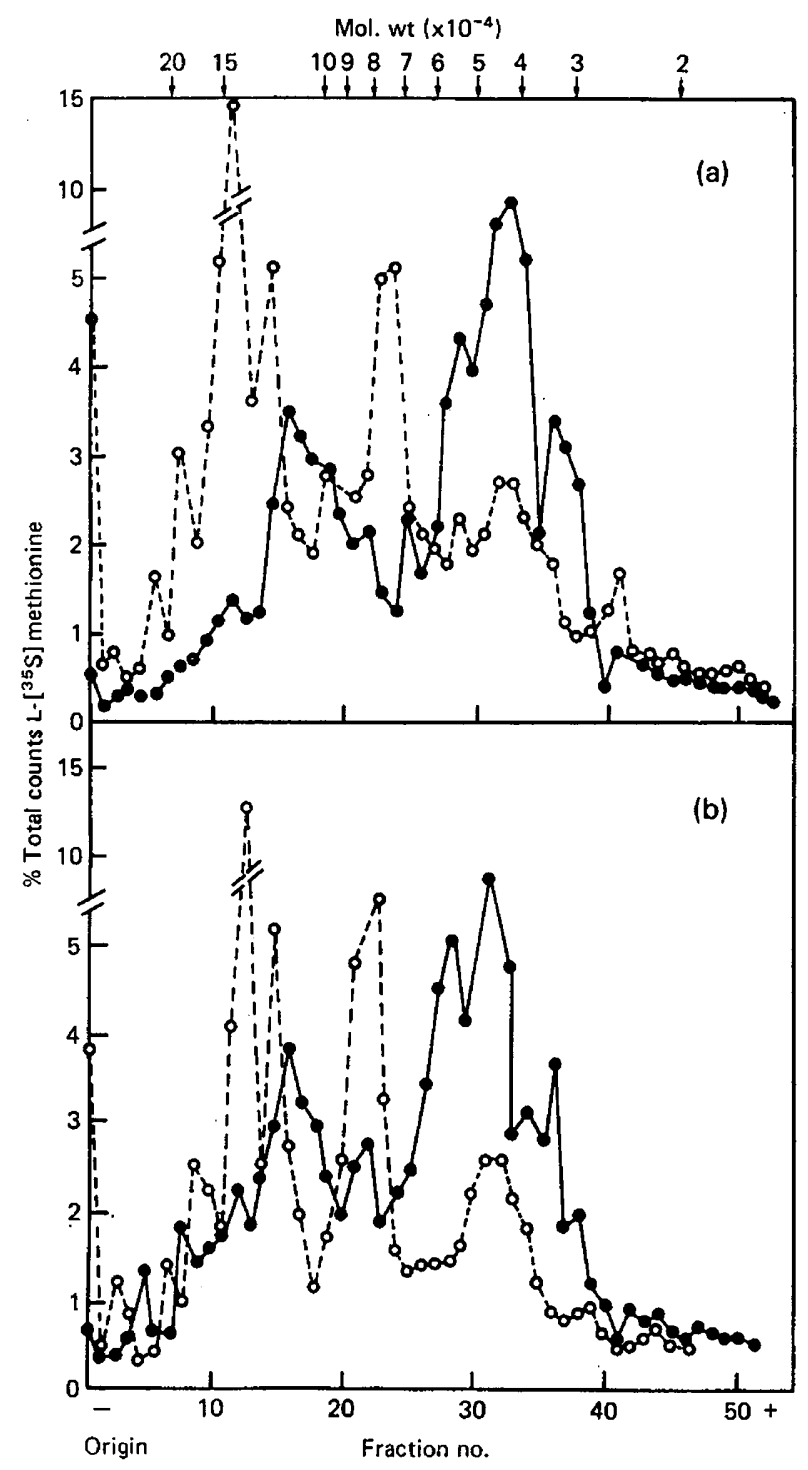

Text-fig. 1. Radioactive counts as a $\%$ of total counts in $0 \cdot 18 \mathrm{~cm}$ polyacrylamide gel fractions (6\% gels) after analysis of $\left[{ }^{35}\right.$ S]methionine-labelled uterine luminal proteins from (a) pregnant $(\bullet)$ and pro-oestrous (o) females. (b) Ovariectomized females were injected with $2 \mathrm{mg}$ progesterone $+1 \mu \mathrm{g}$ oestradiol (•) or oestradiol alone ( 2 injections of $1 \mu \mathrm{g}$ over $48 \mathrm{~h}$ ) (0). Note the similarities of the peaks in (a) and (b). 
tion Spectrometer. The samples analysed electrophoretically consisted of a predetermined number of counts, i.e. $10 \times 10^{4} \mathrm{ct} / \mathrm{min}$ when the incorporation of isotope was high or $2 \times 10^{4}$ when it was low and the results were plotted as a $\%$ of the total counts.

\section{Results}

Samples from 4-20 rats were analysed for each endocrinological state and, in the conditions described, the results, indicated by means of representative examples in Text-figs $1-4$, were highly reproducible. As shown in Text-fig. 1(a), there were qualitative differences between the proteins synthesized during pro-oestrus and on Day 5 of pregnancy. In pregnant females, there were two main groups: one of low molecular weight proteins between $3 \times 10^{4}$ and $6 \times 10^{4}$ (fractions 24-40) and with 3 detectable peaks at molecular weight positions of $3 \times 10^{4}, 4.5 \times 10^{4}$ and $5.5 \times 10^{4}$, and the other group represented proteins with molecular weights between 8 and $10 \times 10^{4}$ (fractions 14-23). Aspirated or flushed samples of uterine fluid from pro-oestrous animals gave identical results. There was only slight incorporation at molecular weight position $4.5 \times 10^{4}$ (fractions 29-34) and the bulk of the radioactivity was incorporated into proteins of molecular weight $7 \cdot 5-8.0 \times 10^{4}$ (fractions $18-24$ ), two peaks, at $12.5 \times$

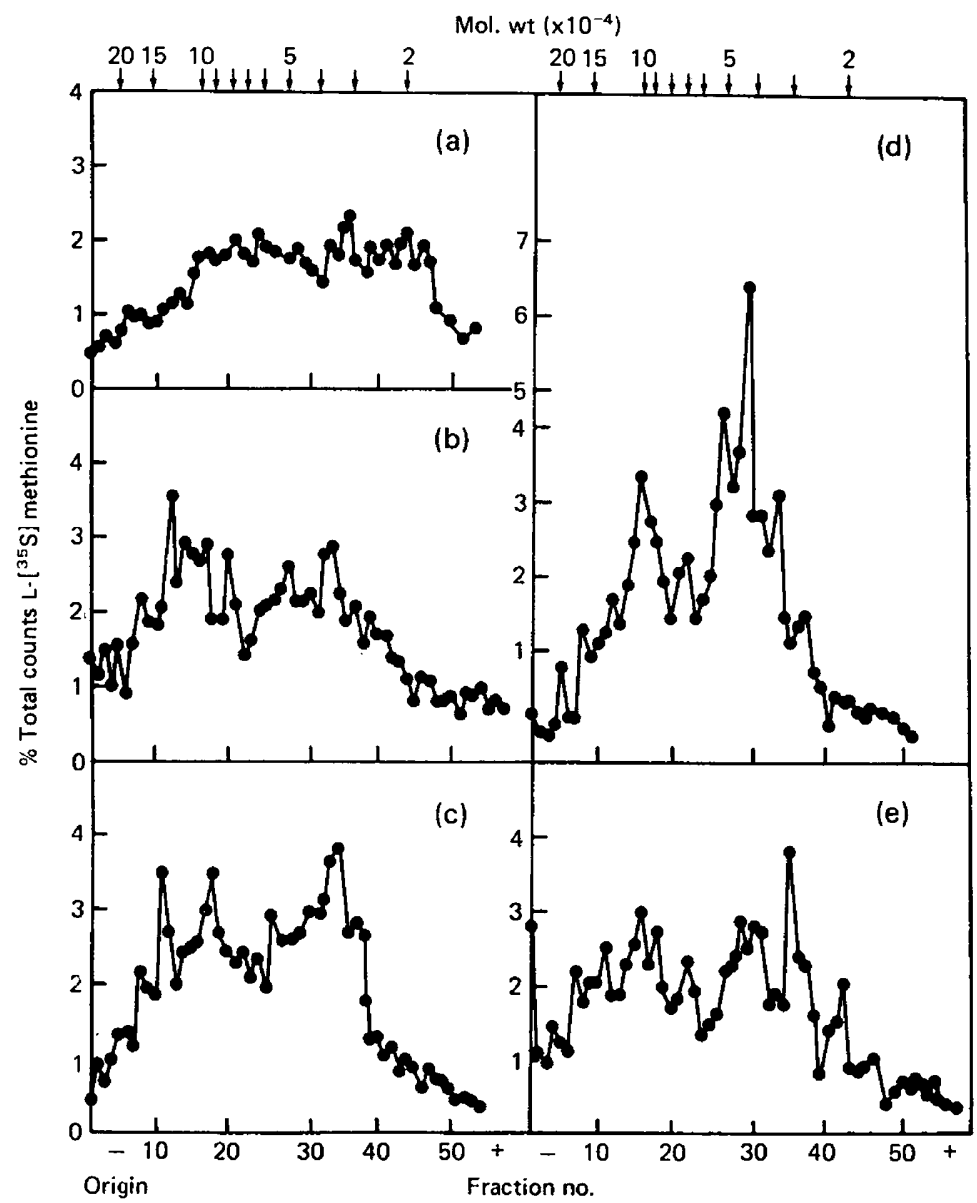

Text-fig. 2. Time-course changes in the appearance of ${ }^{35}$ S] methionine-labelled proteins in the uterineluminal fluid of ovariectomized females after (a) injections of $2 \mathrm{mg}$ progesterone alone, and at different times when $1 \mu \mathrm{g}$ oestradiol was injected with the progesterone: (b) $0-6 \mathrm{~h}$, (c) $6-12 \mathrm{~h}$, (d) $12-18 \mathrm{~h}$, (e) $18-24 \mathrm{~h}$. Note the similarities between the pattern in (d) and that shown in Text-fig. 1(a) for pregnant females. 


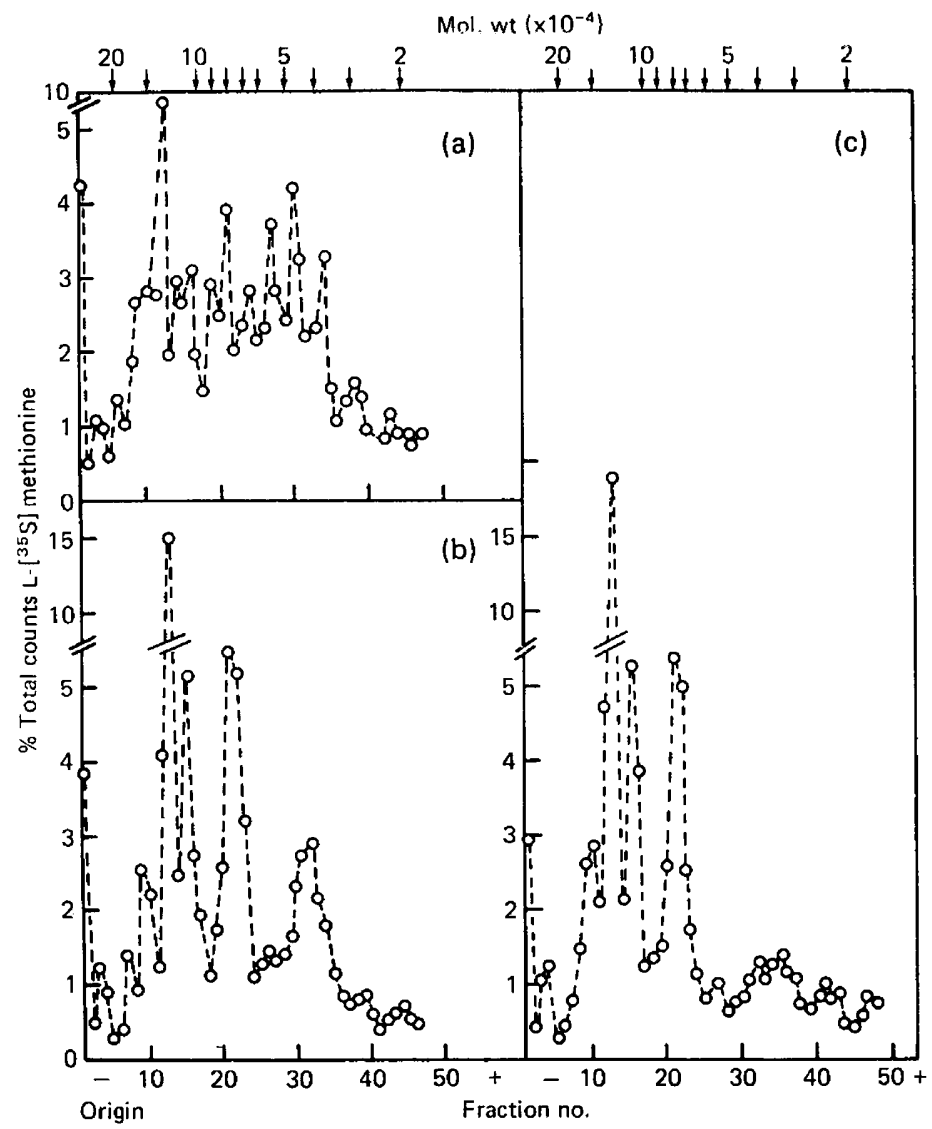

Text-fig. 3. Time-course changes in the appearance of $\left.{ }^{35} S\right]$ methionine-labelled proteins in the uterine luminal fluid of ovariectomized females treated with oestradiol alone: (a) one injection, $24 \mathrm{~h}$, (b) two injections, $48 \mathrm{~h}$, (c) four injections, $96 \mathrm{~h}$.

$10^{4}$ (fractions 14-16) and $13.5 \times 10^{4}$ (fractions 11-14) being prominent. Several other minor peaks were evident in both samples. About 4-5\% of the proteins were found at the origin of the gel columns, but about $90 \%$ of the proteins penetrated the gels under these conditions.

The proteins found in the lumen during pregnancy and pro-oestrus were also found in the samples from ovariectomized females injected with appropriate hormones (Text-fig. 1b). In Group I females (oestrogen + progesterone), the pattern of synthesis most similar to that found on Day 5 of pregnancy was detected at 12-18 h after the last hormone injection (Text-fig. 2). The effect was transitory and the protein peaks were less well defined by 18-24 h after the injection. The proteins detected on Day 3 of pregnancy were not very distinct but were similar to those shown in Text-fig. 2(b). The proteins found during pro-oestrus were induced in the ovariectomized females given oestradiol alone (Group II: Text-fig. 3). A protein of molecular weight $13.5 \times 10^{4}$ (fractions 11-14), prominent in the pro-oestrous samples, was detected after one injection of oestradiol, but $24 \mathrm{~h}$ after the second oestradiol injection the proteins were very similar to those found at pro-oestrus. The profiles remained the same after two further injections of oestradiol at $24 \mathrm{~h}$ intervals. In the females given 4 oestradiol injections and 2 progesterone injections there was very little fluid in the uteri for aspiration, and the uteri appeared progestational, but the distribution of radiolabelled proteins remained qualitatively similar to that of pro-oestrous fluids.

Cycloheximide blocked virtually all protein synthesis and secretion when given simultaneously with methionine (Text-fig. 4a). Some proteins of the lower molecular weights were detected when the 


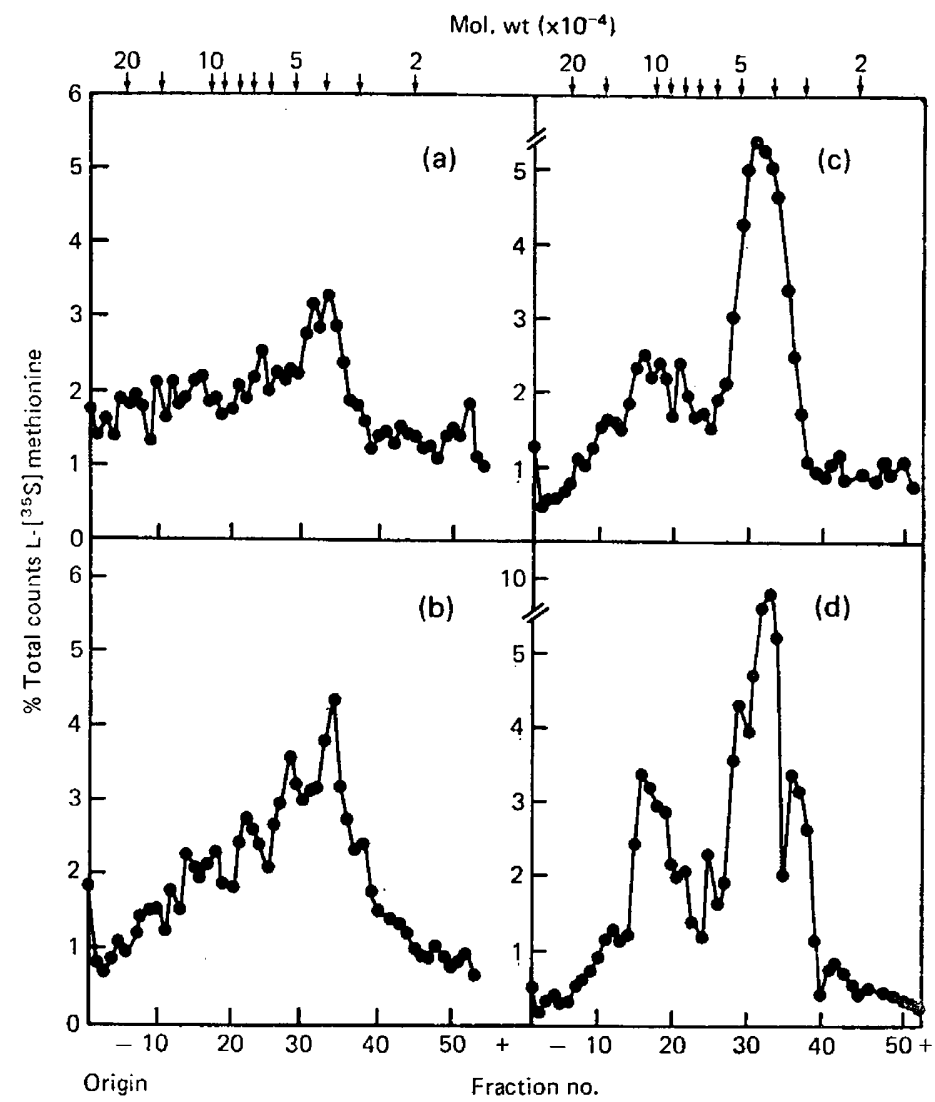

Text-fig. 4. Effects of cycloheximide $(400 \mu \mathrm{g} / \mathrm{female})$ on the incorporation of $\left[{ }^{35} \mathrm{~S}\right] \mathrm{methionine}$ into uterine luminal proteins of pregnant rats (Day 5). Cycloheximide was given (a) simultaneously with the isotope, (b) $2 \mathrm{~h}$ or (c) $4 \mathrm{~h}$ after the instillation of $\left[{ }^{35} \mathrm{~S}\right]$ methionine. (d) Control without cycloheximide.

drug was administered at $2 \mathrm{~h}$ and especially at $4 \mathrm{~h}$ after methionine instillation (Text-figs $4 \mathrm{~b}$ and $4 \mathrm{c}$ ).

After i.p. injection of $\left[{ }^{35}\right.$ S]methionine, the incorporation into serum proteins was slightly greater than after intrauterine injection, but the incorporation into the luminal proteins of pro-oestrous or pregnant rats was only $0 \cdot 2-2 \%$ of that found after intraluminal injection of the isotope and no distinct proteins were detected in the uterine fluids. In the females receiving methionine in one horn and PBS in the other radiolabelled proteins were detected only in the horns receiving the isotope.

\section{Discussion}

The qualitative differences between the radiolabelled uterine luminal proteins at pro-oestrus and those during pregnancy (Day 5) are probably due to the high oestrogen levels during pro-oestrus and the synergistic effects of progesterone and oestradiol during pregnancy. This inference is supported by the ability to reproduce similar changes in spayed females treated with appropriate exogenous hormones although the 'pro-oestrous' response in spayed females was not modified when 2 injections of progesterone were given. It is possible to make these females respond with the same pattern as pregnant females if they are left without treatment for at least 2 days before a schedule of daily treatment with progesterone and a terminal injection of oestradiol (M. A. H. Surani, unpublished).

The proteins appear to be uterine specific. The small amount of radiolabelled proteins present in the uterine lumen after i.p. injection of isotope suggests that, if they are derived from serum, transudation of labelled serum proteins is not a significant contributory factor. It is possible that some of the 
labelled proteins in the uterine lumen after an i.p. injection of precursor are synthesized in the uterus because there seems no reason why the isotope should not reach the uterine cells directly. Labelled proteins were also found only in the lumen on the side of isotope injection. These combined studies indicate that almost all of the radiolabelied proteins detected in the lumen after an intraluminal injection of precursor, and with the experimental procedures employed, are synthesized locally. The suppression of synthesis of labelled proteins when cycloheximide was administered with the isotope was presumably due to its blocking action of the hormone-dependent RNA polymerase activity in the uterus (Hamilton, Widnell \& Tata, 1968; Baulieu, Wira, Milgrom \& Raynaud-Jamet, 1972). The results from administration of the drug at different times suggest that the lower molecular weight proteins are synthesized more rapidly than those of higher molecular weight on Day 5 of pregnancy.

The amount of serum proteins in relation to the total protein content of the uterine luminal fluid is not known, nor is their rate of entry into the lumen. Comparisons with the analyses of static samples (Surani, 1977a) show that the precursor is incorporated into the quantitatively meagre proteins of molecular weight 3.5-6.0 $\times 10^{4}$ as well as into proteins of 8.0-10.0 $\times 10^{4}$ on Day 5 of pregnancy. The labelled proteins of molecular weight 12.5 and $13.5 \times 10^{4}$ in pro-oestrous samples are the major components in the static samples but the proteins of molecular weight 7.5 to $8.0 \times 10^{4}$ obtained in this study have not been equated with any macromolecules visualized on stained gels (Surani, 1977a). The protein of molecular weight 70,000 that is detected within $1 \mathrm{~h}$ after an injection of oestradiol to females experiencing delay of implantation (Surani, 1975a) was not clearly detected as a labelled protein (Text-fig. 2b). It may be synthesized rapidly before the entry of the isotope into uterine cells, be sequestered within the cells and released immediately after an injection of oestradiol, or derived from serum. More precise distinctions between proteins synthesized under different endocrine conditions may be achieved by using dual isotope techniques (Mayol, 1975).

The interactions of oestrogen and progesterone on the uterus may be regulated by the changing hormonal receptor content (Clark, Anderson \& Peck, 1972; Mester, Martel, Psychoyos \& Baulieu, 1974; Hsueh et al., 1975). The template activity of uterine chromatin which is high on Day 5 of pregnancy and at oestrus (O'Grady et al., 1975) is enhanced by oestradiol and progesterone (Teng \& Hamilton, 1968; Glasser \& Clark, 1975). Oestradiol stimulates RNA synthesis (O'Malley \& Means, 1974) through genetic transcription of RNA polymerase activity (Hamilton et al., 1968), and specific nonhistone chromosomal proteins, which may be important for gene transcription, are detected in uterine cells (Cohen \& Hamilton, 1975). New species of nuclear RNA have been found on Day 5 of pregnancy in the rat (Heald \& O'Hare, 1973). Hitherto, consideration has mainly been of the early production of a few cytoplasmic proteins, such as the induced protein (Gorski, 1973; Somjen, Somjen, King, Kaye \& Lindner, 1973) postulated to bind to the chromatin to bring about further changes in gene expression (see Cohen \& Hamilton, 1975). Generalized increase in protein synthesis during cytodifferentiation has not been considered in detail, but some of the luminal proteins may be secretory products of differentiated cells, although the cell types from which they originate remain to be established. In the chick oviduct, glandular epithelium produces ovalbumin in response to oestradiol but avidin is produced by goblet cells in an oestradiol-primed oviduct only after treatment with progesterone (O'Malley \& McGuire, 1968, 1969). The synthesis of these cell specific proteins is associated with the detection of new species of nuclear RNA in response to the steroids (O'Malley \& McGuire, 1969). More than one cell type, responding differently to hormones, may be involved in the production of uterine luminal proteins in the rat.

The probable role of uterine proteins in influencing blastocysts has been considered previously (Surani, 1975a, b, 1976, 1977b; Gore-Langton \& Surani, 1976; Webb \& Surani, 1975). No distinct proteins can be detected in females given progesterone only, an endocrine state equivalent to that when embryos are metabolically quiescent, presumably as an adaptation to a suboptimal environment. When proteins resembling those found on Day 5 of pregnancy are induced 12-18 h after a single injection of oestradiol, it is possible for blastocysts to implant (Surani, 1977b). By $24 \mathrm{~h}$ after oestradiol injection the proteins are less distinct, the uterus enters into a refractory phase, and embryos transferred at this time fail to implant (Psychoyos, 1973). A strong temporal correlation between the changes in the uterine luminal proteins and implantation is further emphasized by these studies. 
I thank Dr R. G. Edwards for helpful suggestions and Dr R. J. B. King for his advice on scintillation counting procedures. The work was supported by a Medical Research Council Project Grant and the Ford Foundation. Competent assistance by Andrea Burling is gratefully acknowledged.

\section{References}

Albers, H.J. \& Neves e Castro, M. (1961) The protein component of rat uterine fluid. Fert. Steril. 12, 142149.

Baulieu, E.E., Wira, C.R., Milgrom, E. \& RaynaudJAMET, C. (1972) Ribonucleic acid synthesis and oestradiol action in the uterus. Acta endocr., Copenh., Suppl. 168, 396-419.

BeCK, L.R. \& Boots, L.R. (1973) Immunologic studies on rat uterine fluid. Contraception 7, 125-131.

Clark, J.H., ANDerson, J.N. \& PECK, E.J., JR (1972) Receptor-estrogen complex in the nuclear fraction of rat uterine cell during the estrous cycle. Science, N. $Y .176,528-550$.

Cohen, M.E. \& Hamilton, T.H. (1975) Effect of estradiol-17 $\beta$ on the synthesis of specific uterine nonhistone chromosomal proteins. Proc. natn. Acad. Sci. U.S.A. 72, 4346-4350.

Glasser, S.R. \& Clark, J.H. (1975) Determinant role for progesterone in the development of uterine sensitivity to decidualization and ovo-implantation. In The Developmental Biology of Reproduction, pp. 311-346. Eds C. L. Market \& J. Papaconstantinou. Academic Press, New York.

Gore-Langton, R.E. \& SURANI, M.A.H. (1976) Uterine luminal proteins of mice. J. Reprod. Fert. 46, 271-274.

GORSKI, J. (1973) Estrogen binding and control of gene expression in the uterus. In Handbook of Physiology, Vol. 7, pp. 525-536. Ed. R. O. Greep \& E. B. Astwood. Waverly Press, Baltimore, Maryland.

Hamilton, T.H., Widnell, C.C. \& TAtA, J.R. (1968) Synthesis of ribonucleic acid during early estrogen action. J. biol. Chem. 243, 408-417.

Heald, P.J. \& O'Hare, A. (1973) Changes in rat uterine RNA during early pregnancy. Biochim. biophys. Acta 324, 86-92.

Hsueh, A.J., PECK, E.J. \& ClARK, J.H. (1975) Progesterone antagonism of oestrogen receptors and oestrogeninduced uterine growth. Nature, Lond. 254, 337-339.

Kunitake, G.M., Nakamura, R.M., Wells, B.G. \& MOYER, D.L. (1965) Studies on uterine fluid. I. Disc electrophoretic and disc-gel Ouchterlony analysis of rat uterine fluid. Fert. Steril. 16, 120-124.

MaYol, R.F. (1975) Studies on the synthesis of oestrogen-specific uterine proteins. Comparisons of methods of quantitative evaluation of doubleisotope peaks. Molec. cell. Endocr. 2, 133-139.

Mester, I., Martel, D., Psychoyos, A. \& Baulieu, E.E. (1974) Hormonal control of oestrogen receptor in uterus and receptivity for implantation in the rat. Nature, Lond. 250, 776-778.

O'Grady, J.E., Moffat, G.E., McMinn, L., Vass, M.A., O'HARE, A. \& HEALD, P.J. (1975) Uterine chromatin template activity during the early stages of pregnancy in the rat. Biochim. biophys. Acta 407, 125-132.
O'Malley, B.W. \& Means, A.R. (1974) Female steroid hormones and target cell nuclei. Science, N.Y. 183, 610-620.

O'Malley, B.W. \& McGuire, W.L. (1968) Studies on the mechanism of estrogen-mediated tissue differentiation: regulation of nuclear transcription and induction of new RNA species. Proc. natn. Acad. Sci. U.S.A. 60, 1527-1534.

O'Malley, B.W. \& McGuire, W.L. (1969) Progesterone-induced synthesis of a new species of nuclear RNA. Endocrinology 68, 63-68.

Psychoyos, A. (1973) Hormonal control of ovoimplantation. Vitams Horm. 31, 201-256.

Somjen, D., Somjen, G., King, R.J.B., Kaye, A.M. \& LINDNER, H.R. (1973) Nuclear binding of oestradiol-17 $\beta$ and induction of protein synthesis in the rat uterus during postnatal development. Biochem. J. 136, 25-33.

SURANI, M.A.H. (1975a) Hormonal regulation of proteins in the uterine secretion of ovariectomized rats and the implications for implantation and embryonic diapause. J. Reprod. Fert. 43, 411-417.

SURANI, M.A.H. (1975b) Zona pellucida denudation, blastocyst proliferation and attachment in the rat. J. Embryol. exp. Morph. 33, 343-353.

SurANI, M.A.H. (1976) Uterine luminal proteins at the time of implantation in rats. J. Reprod. Fert. 48, 141145.

SURANI, M.A.H. (1977a) Qualitative and quantitative examination of the proteins of rat uterine luminal fluid during pro-oestrus and pregnancy and comparison with those of serum. J. Reprod. Fert. 50, 281287.

SURANI, M.A.H. (1977b) Cellular and molecular approaches to blastocyst uterine interactions at implantation. In Development in Mammals, Vol. 1, pp. 245-305. Ed. M.H. Johnson. Elsevier/NorthHolland Bio-medical Press, Amsterdam (in press).

TACHI, C., TACHI, S., \& LINDNER, H.R. (1972) Modification by progesterone of oestradiol-induced cell proliferation, RNA synthesis and oestradiol distribution in the rat uterus. J. Reprod. Fert. 31, 59-76.

TENG, C.-S. \& Hamlton, T.H. (1968) Role of chromatin in estrogen action in the uterus. II. Hormoneinduced synthesis of nonhistone acidic proteins which restore histone-inhibited DNA-dependent RNA synthesis. Proc. natn. Acad. Sci. U.S.A. 63, 465-476.

WebB, F.T.G. \& SURANI, M.A.H. (1975) Influence of environment on blastocyst proliferation, differentiation and implantation. In Regulation of Growth and Differentiated Function in Eukaryote Cells, pp. 519 522. Ed. G. P. Talwar. Raven Press, New York.

YING, S.Y. \& GREEP, R.O. (1972) Inhibition of implantation with antibody against uterine fluid and blastocysts in the rat. Contraception 6, 93-102. 